\title{
Root Properties of Plants Used for Soil Erosion Control in the Usambara Mountains, Tanzania
}

\author{
S. B. Mwango ${ }^{1^{*}}$, B. M. Msanya ${ }^{1}$, P. W. Mtakwa ${ }^{1}$, D. N. Kimaro ${ }^{2}$, \\ J. Deckers ${ }^{3}$, J. Poesen ${ }^{3}$, V. Massawe ${ }^{1}$ and I. Bethuel ${ }^{1}$ \\ ${ }^{1}$ Department of Soil Science, Sokoine University of Agriculture, P.O. Box 3008 Chuo Kikuu, \\ Morogoro, Tanzania. \\ ${ }^{2}$ Department of Agricultural Engineering and Land Planning, Sokoine University of \\ Agriculture, P.O. Box 3003 Chuo Kikuu, Morogoro, Tanzania. \\ ${ }^{3}$ Department of Earth \& Environmental Sciences, KU Leuven, Celestijnenlaan 200 E, B-3001
}

Heverlee, Belgium.

\section{Authors' contributions}

This work was carried out in collaboration between all authors. Author SBM designed the study, wrote the protocol, conducted field work, performed statistical analysis, and wrote the first draft of the manuscript. Author BMM designed the study, conducted field work, managed the literature searches and edited drafts. Author PWM designed the study, conducted field work and edited drafts and authors DNK, JD and JP designed the study and edited drafts. Authors VM and IB conducted field and laboratory work. All authors read and approved the final manuscript.

\section{Article Information}

DOI: 10.9734/IJPSS/2014/12102 Editor(s):

(1) Paola Crinò, Unit of Sustainable Development and Innovation of the Agro-Industrial System, Italy.

Reviewers:

(1) Anonymous, Juarez University, Mexico. (2) Anonymous, , Maseno University, Kenya. Peer review History: http://www.sciencedomain.org/review-history. .php?iid=620\&id=24\&aid=5888

\section{ABSTRACT}

Plant roots may have a strong erosion-reducing effect. However, little is known about root characteristics of tropical plants used for erosion control. A study was thus conducted in the Western Usambara Mountains, Tanzania to investigate rooting characteristics of 
Guatemala grass (Tripsacum andersonii), Napier grass (Pennisetum purpureum) and Tithonia shrub (Tithonia diversifolia), also referred to as wild sunflower, and to evaluate their potential for erosion control. For each plant species, mean root diameter (D), root density (RD), root length density (RLD) and root area ratio (RAR) were assessed for six plants in each species and relative soil detachment rate (RSD) predicted. Mean RD values in the $0-0.4 \mathrm{~m}$ soil depth for Majulai village and Migambo village respectively were 50.9 and $58.6 \mathrm{~kg} / \mathrm{m}^{3}$ for Guatemala grass, 30.4 and $31.3 \mathrm{~kg} / \mathrm{m}^{3}$ for Napier grass and 22.1 and $23.0 \mathrm{~kg} / \mathrm{m}^{3}$ for Tithonia shrub. RLD values were 35.9 and $45.0 \mathrm{~km} / \mathrm{m}^{3}$ for Guatemala grass, 31.3 and $150.0 \mathrm{~km} / \mathrm{m}^{3}$ for Napier grass and 10.5 and $6.4 \mathrm{~km} / \mathrm{m}^{3}$ for Tithonia shrub. Predicted RSD values were $4.43^{*} 10^{-12}$ and $1.20^{*} 10^{-14}$ for Guatemala grass, $6.10^{*} 10^{-5}$ and $2.74^{*} 10^{-4}$ for Napier grass and $4.43^{*} 10^{-3}$ and $2.24^{*} 10^{-4}$ for Tithonia shrub in the $0-0.4 \mathrm{~m}$ soil depth. The results indicate that Guatemala grass has a higher potential to reduce soil erosion rates by concentrated flow as compared to Napier grass or Tithonia shrub in the $0-0.4 \mathrm{~m}$ soil depth. These findings have implications on the selection and use of appropriate plants for soil erosion control.

Keywords: Root density; root length density; Napier grass; Guatemala grass; Tithonia shrub; soil conservation.

\section{INTRODUCTION}

In the highlands of the Usambara Mountains, in Northern Tanzania, farm lands are located on steep slopes and are highly susceptible to soil erosion by water. Soil erosion is a major problem impacting agricultural productivity and river discharge [1]. In view of the cool tropical climate, the Usambara Mountains are suitable to many crops such as vegetables, fruits, potatoes, beans and maize many of which cannot be grown in the lowlands. There is a lot of pressure in the land resource in the Usambara Mountains which results in significant water and tillage erosion [2]. Local farmers and development organizations including the Soil Erosion Control and Agro forest Program (SECAP) and the African Highland Initiative Program (AHI) promote soil conservation measures at farm level using various measures. Examples of measures were bench terraces, Miraba, agro- forestry, Fanya Juu terraces and ridges. Miraba is an indigenous practice widely adopted by farmers in the Usambara Mountains. It comprises rectangular grass strips (ca. $0.5 \mathrm{~m}$ ) that run parallel and perpendicular to the contour lines [3] using either Guatemala or Napier grass. Other soil erosion control measures such as bench terraces and Fanya Juu terraces are usually stabilized by Guatemala grass, Napier grass or wild sunflower (Tithonia shrubs) and in a few occasion sugarcane and/or banana are used. Napier grass is mostly preferred as it is also used for forage, whereas, Guatemala grass is appreciated for its drought resistance.

The studied plants, particularly Napier and Guatemala grasses, have been documented to be used as fodder in many tropical countries including Tanzania and in the Usambara Mountains. Their popularity relates to their wide ecological range (from the coast to over 2,000 meters), high yield and ease of propagation and management [4]. As surprisingly little in-depth research has been focusing on these grasses, in the West Usambaras, this study aims to contribute by exploring their rooting characteristics and their effectiveness to control concentrated flow erosion. Roots bind particles in the topsoil, which offer protection to soil that is under pressure of detachment by sheet flow or concentrated flow $[5,6]$. The presence of roots also increases the soil's roughness, thereby providing a greater capacity for infiltration and for reducing surface runoff velocity [7]. In Sub- Saharan Africa, including Tanzania, most soil erosion studies focused on the effects of the above-ground vegetation, 
whereas much less attention has been paid to the effects of plant roots on water erosion rates [8,9]. Research on the effects of root characteristics on soil erosion rates has been scanty in Sub-Saharan Africa [e.g.8] and particularly in Tanzania and in the Usambara Mountains where it has never been done before. Some experimental studies by [10] on the effects of roots on reducing soil erosion rates have been conducted in Belgium and Spain and have reported that root systems of some plants have a large potential to reduce soil erosion rates during concentrated flow. In these studies relative soil detachment rates compared to bare soil ranged between $0.3 \times 10^{-12}$ and 0.7 for the $0.10 \mathrm{~m}$ thick topsoil.

Therefore, this study aims to investigate rooting characteristics of some plants frequently used for soil erosion control, namely Guatemala (Tripsacum andersonii), Napier (Pennisetum purpureum) and wild sunflower (Tithonia diversifolia) in order to explore why they are used for soil erosion control and to identify the most effective plants for soil erosion control in croplands of the Usambara Mountains. The objectives are (i) to determine root characteristics of the selected plants, (ii) to compare root characteristics of the selected plants, and (iii) to identify the most effective plants for controlling soil erosion by concentrated flow by using empirical relationships published by [7].

\section{MATERIALS AND METHODS}

\subsection{Study Area}

This study was conducted in Migambo and Majulai villages, West Usambara Mountains, Lushoto District, Tanzania (Fig. 1). located between $38^{\circ} 15^{\prime} \mathrm{E}$ to $38^{\circ} 24^{\prime} \mathrm{E}$ and $4^{\circ} 34^{\prime} \mathrm{S}$ to $4^{\circ}$ $48^{\prime} \mathrm{S}$. Migambo has a humid, cold climate with daily air temperature ranging from $12-17^{\circ} \mathrm{C}$, maximum in March and minimum in July and annual precipitation between 792 and 2,296 $\mathrm{mm}$ usually occurring from October to December (short rains) and late February to May (long rains) [3]. Majulai has a dry, warm climate with daily air temperature ranging between 16 and $21^{\circ} \mathrm{C}$, maximum in March and minimum in July, and annual precipitation of 500 to $1,700 \mathrm{~mm}$ mainly occurring from mid-October to December (short rains) and late February to May (Long rains). The soils of Migambo village according to [11] and that of Majulai village and topographical properties of the study area are presented in (Table 1).

The study area is characterized by cropland on slopes and valley bottoms; and settlements on depressions, ridge summits and slopes. The average farm size is about 1.4 ha per household for rain-fed agriculture [12] with low input traditional farming where cultivation is by hand hoes. Vegetables such as carrots, onions, tomatoes, cabbages, and peas are grown as sole crops in valleys under rain-fed or under traditional irrigated schemes where groups of farmers construct local storage dams and canals to irrigate their crops. Beans, maize, round potatoes and fruits namely peaches, plums, pears, avocado and banana are grown on ridge slopes under rain- fed mixed cropping systems with either of the fruits cropped with beans, maize and round potatoes. Round potatoes are also grown in valleys as sole crop or intercropped with maize. Maize is usually grown during short rains and beans during long rains. 


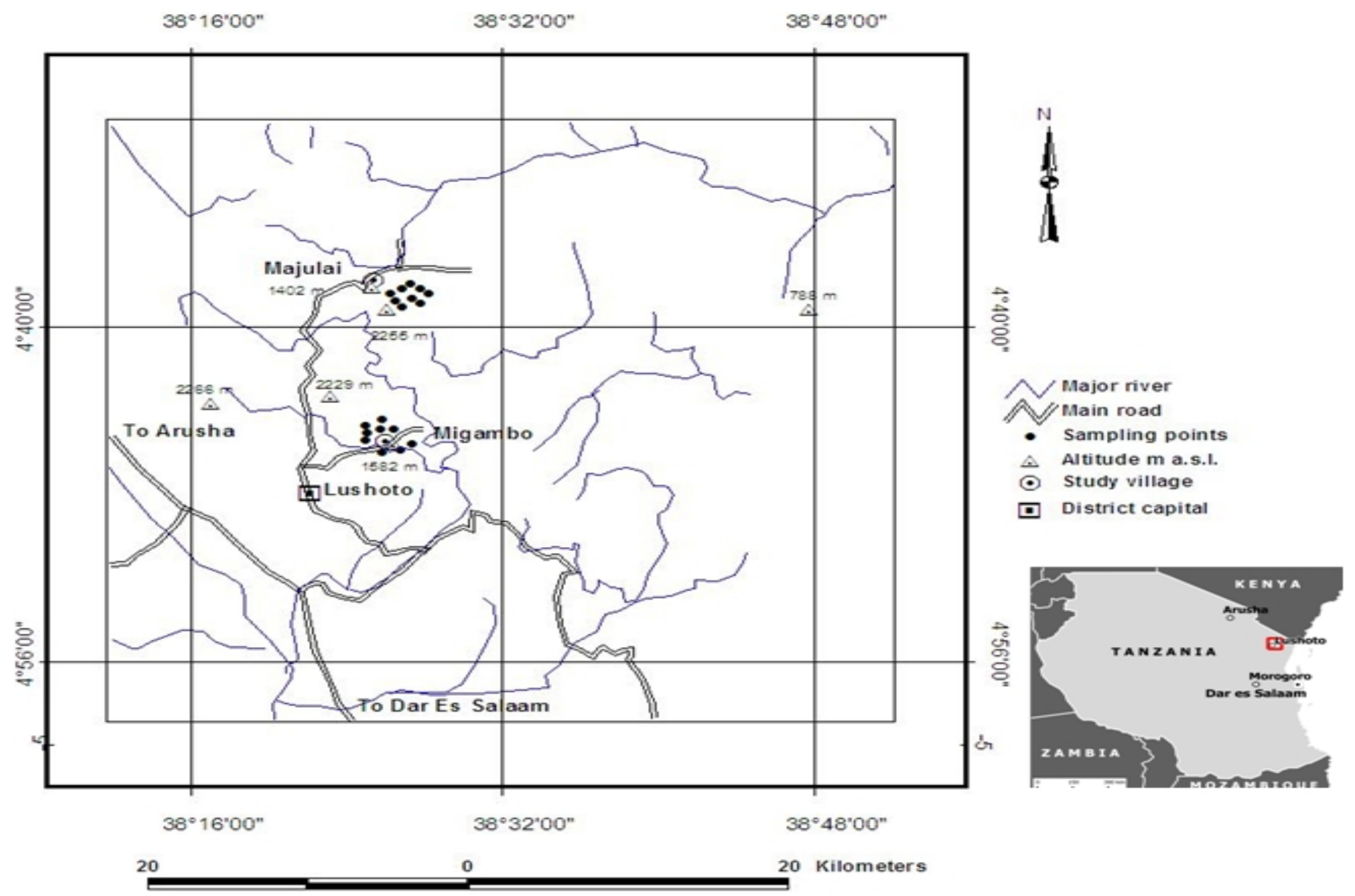

Fig. 1. Location map of Migambo and Majulai Villages, Lushoto District, Tanzania 
Table 1. Soil and topographical properties of the study area

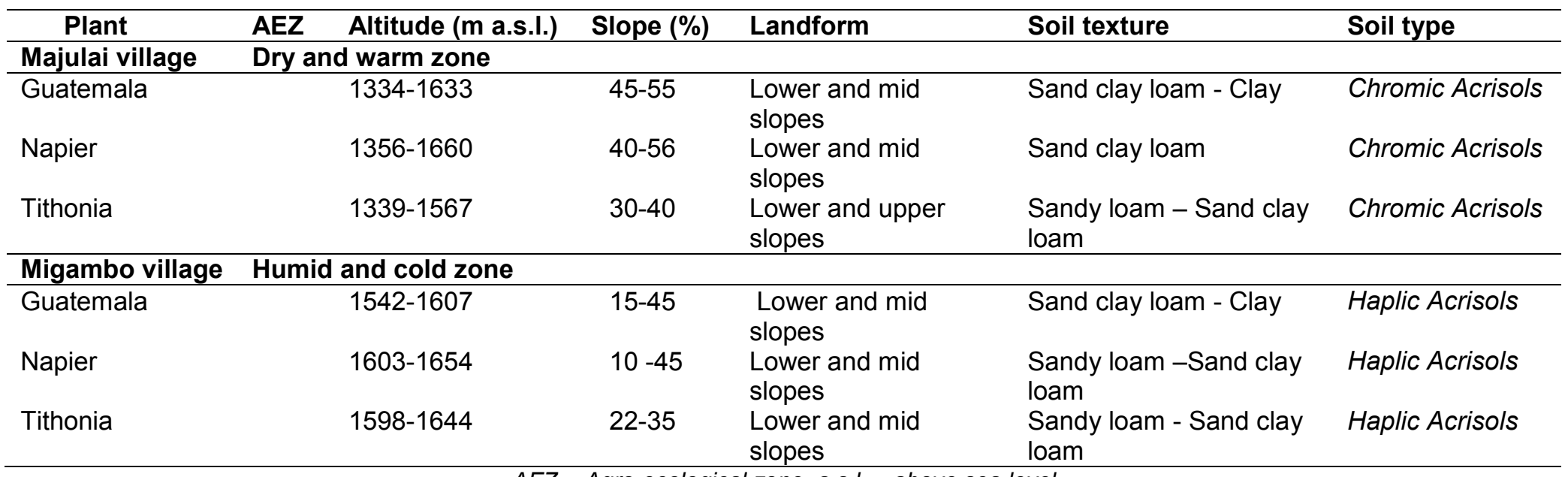

AEZ = Agro-ecological zone, a.s.l. = above sea level 


\subsection{Data Collection}

Medium-size adult plants 2 to 2.5 years old (for comparison purposes) were selected for root sampling in croplands of the study area. The age of the plants were obtained by asking farmers. Plant root characteristics such as root density and root length density have direct relations with age and size of the plant, thus it was necessary to collect root samples from plants of the same age and size for a reliable comparison [13]. In each village 3 plants from each species were randomly sampled with respect to landform i.e. at the upper, mid and lower slopes, the plants were excavated and analyzed for rooting characteristics. Root sampling was done by excavating six individual plants per species at their natural conditions as described by [14]. The excavation method provided a clear picture of the rooting system of the plant under natural conditions. Around the plant a contour was delineated at a distance from the plant stem equaling the orthogonal projected radius of the above-ground biomass; a soil column was then dug around this orthogonal projection as deep as possible. The soil material was carefully removed by hand and cleaning with water from the excavated soil column starting from the top to the bottom. After excavation, digital photos were taken to record the rooting systems. Height and diameter of the orthogonal projection of the aboveground biomass were measured with a ruler. The roots were cut into soil depth classes of $0.1 \mathrm{~m}$ for the upper $0.4 \mathrm{~m}$ soil depth, collected in plastic bags for each soil depth class and per plant species for laboratory analysis. Composite top soil samples around the studied plant species were collected at a soil depth $0-30 \mathrm{~cm}$ for soil texture determination by hydrometer method according to the laboratory manual of [15]. In the laboratory, roots from each soil depth class were divided over 4 diameter classes: i.e. $<2 \mathrm{~mm}, 2-5 \mathrm{~mm}, 5-10$ $\mathrm{mm}$ and $>10 \mathrm{~mm}$ [10] using digital caliper. The roots were oven dried for 24 hours at $60-65$ ${ }^{\circ} \mathrm{C}$ to obtain dry mass [16]. Digital photos of roots from each depth class were taken and total root length was determined using image analysis (MapInfo Professional 11.5) [17].

The rooting characteristics determined include: root diameter (D) $(\mathrm{mm})$, root density (RD) mass of dry root biomass per unit volume of root-permeated soil $\left(\mathrm{kg} / \mathrm{m}^{3}\right)$, root length density (RLD) $\left(\mathrm{km} / \mathrm{m}^{3}\right)$. The root area ratio (RAR) was also determined as a root parameter in this study. Relative soil detachment rate (RSD) was estimated using an empirical relationship established by [7] for the determination of the most effective plant for soil erosion control:

$$
\text { Root density (RD) } \mathrm{kg} / \mathrm{m}^{3}=\mathrm{MD} / \mathrm{V}
$$

Where $M_{D}(\mathrm{~kg})$ = dry living root mass, $V\left(\mathrm{~m}^{3}\right)$ = volume of the corresponding soil cylinder [5]

$$
\text { Root length density (RLD) } \mathrm{km} / \mathrm{m}^{3}=\mathrm{L}_{\mathrm{R}} / \mathrm{V}
$$

Where $L_{R}$ is the total length of the roots $(\mathrm{km}), V$ is the volume of root permeated soil sample $\left(\mathrm{m}^{3}\right)[5]$

$$
\text { Root area ratio }(R A R)=R L D \times R C S A
$$

Where RCSA is mean cross-sectional area of a single root $\left(\mathrm{m}^{2}\right)[5]$

$$
\text { Relative soil detachment rate }(R S D)=e^{-1.45 R D 1<D<5 m m} e^{-0.47 R D D ~}>5 \mathrm{~mm}
$$

Where $\mathrm{D}$ is the root diameter $(\mathrm{mm})[7]$. 


\subsection{Statistical Analysis}

The data on RD, RLD, RAR and RSD were subjected to Analysis of Variance (ANOVA) using Genstat 14 statistical software [18]. Least Significant Difference $\left(\operatorname{LSD}_{0.05}\right)$ was used to detect mean differences between the studied plants.

\section{RESULTS AND DISCUSSION}

\subsection{General Characteristics of the Studied Plant Species}

The studied plant characteristics above and below ground are presented in Table 2. Most root distribution occurred within $0-0.4 \mathrm{~m}$ soil depth and thus only roots within this soil depth were considered for further analysis. The mean height $(\mathrm{H})$ of the measured Guatemala grasses was $1.4 \mathrm{~m}$ in Majulai and $1.2 \mathrm{~m}$ in Migambo village and mean diameter of the rooted soil volume $\left(D_{s v}\right)$ was $0.43 \mathrm{~m}$ in Majulai and $0.48 \mathrm{~m}$ in Migambo village; the mean height of Napier grasses was $1.62 \mathrm{~m}$ in Majulai and $1.63 \mathrm{~m}$ in Migambo village and mean $\mathrm{D}_{\mathrm{Sv}}$ was $0.38 \mathrm{~m}$ in Majulai and $0.38 \mathrm{~m}$ in Migambo village, whereas the mean height of Tithonia shrub was $1.27 \mathrm{~m}$ in Majulai and $1.26 \mathrm{~m}$ in Migambo village and mean $\mathrm{D}_{\mathrm{Sv}}$ was $0.45 \mathrm{~m}$ in Majulai and $0.53 \mathrm{~m}$ in Migambo village. The slight variability in $D_{\mathrm{Sv}}$ may be due to differences in climatic conditions between the studied villages where Migambo is humid while Majulai has a dry climate.

Table 2. Characteristics of the studied Guatemala, Napier and Tithonia plants

\begin{tabular}{|c|c|c|c|c|c|c|c|c|c|c|}
\hline \multirow[t]{2}{*}{ Plant } & \multirow[t]{2}{*}{ Type } & \multirow[t]{2}{*}{$\mathbf{n}$} & \multirow{2}{*}{$\begin{array}{l}\mathrm{H} \\
(\mathrm{m})\end{array}$} & \multirow{2}{*}{$\begin{array}{l}d \text { max } \\
(\mathrm{m})\end{array}$} & \multirow{2}{*}{$\begin{array}{l}D_{s v} \\
\text { (m) }\end{array}$} & \multicolumn{4}{|c|}{$\%$ of total root mass } & \multirow{2}{*}{$\begin{array}{l}\text { RD } \\
\left(\mathrm{kg} / \mathrm{m}^{3}\right)\end{array}$} \\
\hline & & & & & & $\begin{array}{l}D<2 \\
(\mathrm{~mm})\end{array}$ & $\begin{array}{l}2<D< \\
5(\mathrm{~mm})\end{array}$ & $\begin{array}{l}5<D< \\
10(\mathrm{~mm})\end{array}$ & $\begin{array}{l}D> \\
10(\mathrm{~mm})\end{array}$ & \\
\hline \multicolumn{11}{|l|}{ Majulai } \\
\hline Guatemala & Grass & 3 & 1.4 & 0.5 & 0.4 & 57 & 43 & 0 & 0 & 50.9 \\
\hline Napier & Grass & 3 & 1.6 & 0.5 & 0.4 & 95 & 5 & 0 & 0 & 30.4 \\
\hline Tithonia & Shrub & 3 & 1.3 & 0.5 & 0.5 & 36 & 37 & 21 & 6 & 22.1 \\
\hline \multicolumn{11}{|l|}{ Migambo } \\
\hline Guatemala & Grass & 3 & 1.2 & 0.5 & 0.5 & 78 & 22 & 0 & 0 & 58.6 \\
\hline Napier & Grass & 3 & 1.6 & 0.6 & 0.4 & 100 & 0 & 0 & 0 & 31.3 \\
\hline Tithonia & Shrub & 3 & 1.3 & 0.6 & 0.5 & 31 & 33 & 34 & 2 & 23.0 \\
\hline
\end{tabular}

The mean root distribution values over different root diameter classes for Guatemala grass were $57 \%$ for $D<2 \mathrm{~mm}$ and $43 \%$ for $2<D<5 \mathrm{~mm}$ ) in Majulai; and $78 \%$ for $D<2 \mathrm{~mm}$ and $22 \%$ for $2<D<5 \mathrm{~mm}$ in Migambo village. The mean root distribution values for Napier grass were $95 \%$ for $D<2 \mathrm{~mm}$ and $5 \%$ for $2<D<5 \mathrm{~mm}$ ) in Majulai; and in Migambo village $100 \%$ of the below ground biomass consisted of roots smaller than $2 \mathrm{~mm}$ in diameter. In the case of Tithonia shrub, the mean root distribution values were $36 \%$ for $D<2 \mathrm{~mm}, 37 \%$ for 2 $<\mathrm{D}<5 \mathrm{~mm}, 21 \%$ for $5<\mathrm{D}<10 \mathrm{~mm}$ and $6 \%$ for $\mathrm{D}>10 \mathrm{~mm}$ in Majulai, and $31 \%$ for $\mathrm{D}<2$ $\mathrm{mm}, 33 \%$ for $2<\mathrm{D}<5 \mathrm{~mm}, 34 \%$ for $5<\mathrm{D}<10 \mathrm{~mm}$ and $2 \%$ for $\mathrm{D}>10 \mathrm{~mm}$ in Migambo village. The distribution of roots over different root diameter classes was highly variable for the studied plant species. Moreover, the root architecture (Fig. 2) also showed a large variability among the plant species. Root architecture is used to describe the spatial arrangement of the root system components (geometry), its structure and topology [16]. Root topology refers to how individual root axes are connected to each other through 
branching [19], while geometry includes the shape, the size, the orientation and the spatial location of the components [20]. While Guatemala and Napier grasses have only finebranched fibrous roots, Tithonia shrub has thicker tap root system.

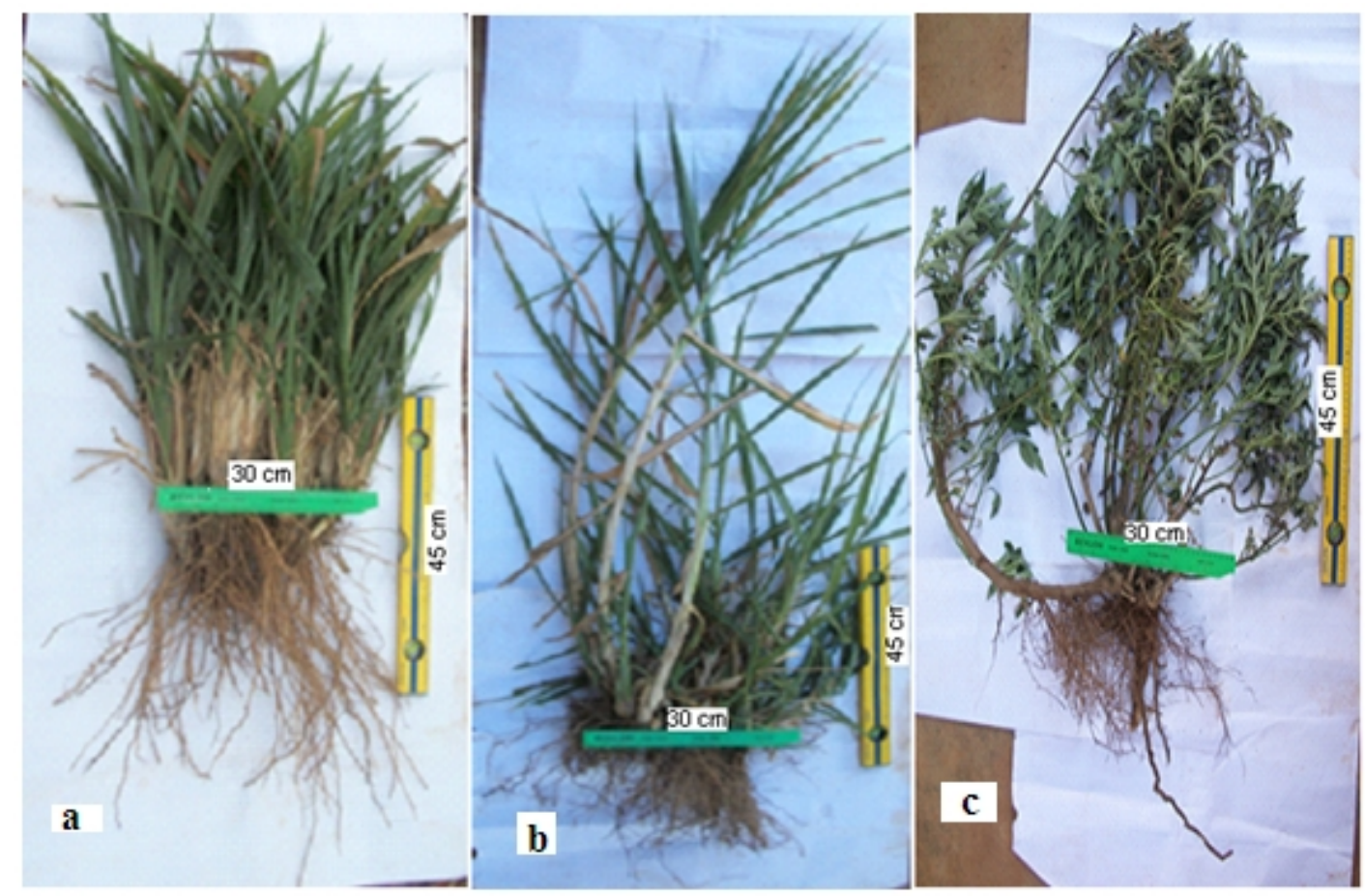

Fig. 2. Illustration of root architecture of Guatemala grass (a), Napier grass (b) and Tithonia shrub (c)

\subsection{Rooting Characteristics of the Studied Plant Species}

In this study, rooting characteristics of the studied plant species are expressed by Root Density (RD), Root Length Density (RLD) and Root Diameter (D) as presented in Table 2 and Fig. 3. Root density (RD) values of the studied plants in Majulai village for the $0-0.4 \mathrm{~m}$ soil depth were $50.9 \mathrm{~kg} / \mathrm{m}^{3}$ (stdev $=7.9 \mathrm{~kg} / \mathrm{m}^{3}$ ) for Guatemala grass, $30.4 \mathrm{~kg} / \mathrm{m}^{3}$ (stdev $=8.4$ $\mathrm{kg} / \mathrm{m}^{3}$ ) for Napier grass and $22.1 \mathrm{~kg} / \mathrm{m}^{3}$ stdev $=12 \mathrm{~kg} / \mathrm{m}^{3}$ ) for Tithonia shrub. In Migambo village, RD values for $0-0.4 \mathrm{~m}$ soil depth were $58.6 \mathrm{~kg} / \mathrm{m}^{3}$ (stdev $=8.9 \mathrm{~kg} / \mathrm{m}^{3}$ ) for Guatemala grass, $31.3 \mathrm{~kg} / \mathrm{m}^{3}$ (stdev $=9.1 \mathrm{~kg} / \mathrm{m}^{3}$ ) for Napier grass, and $23.0 \mathrm{~kg} / \mathrm{m}^{3}$ (stdev $=8.9 \mathrm{~kg} / \mathrm{m}^{3}$ ) for Tithonia shrub. Under similar tropical environment a study by [8] near Lake Victoria in Uganda reported RD for $0-0.4 \mathrm{~m}$ soil depth were $20.6 \mathrm{~kg} / \mathrm{m}^{3}$ for Paspalum, $7.6 \mathrm{~kg} / \mathrm{m}^{3}$ for Lemon grass, $3.8 \mathrm{~kg} / \mathrm{m}^{3}$ for Elephant grass and $5.1 \mathrm{~kg} / \mathrm{m}^{3}$ for Sugarcane. Root density values of pasture grasses located in the loess belt of Belgium, range between 4 and 38 $\mathrm{kg} / \mathrm{m}^{3}\left(\mathrm{n}=32\right.$, mean $=14 \mathrm{~kg} / \mathrm{m}^{3}$, stdev $\left.=7 \mathrm{~kg} / \mathrm{m}^{3}\right)$. This is indicating that RD of the studied plants are higher than those of Paspalum, Lemon grass and Elephant grass in Uganda and pasture grasses in Belgium.

The RLD values for the $0-0.4 \mathrm{~m}$ soil depth were $35.9 \mathrm{~km} / \mathrm{m}^{3}$ (stdev $=7.2 \mathrm{~km} / \mathrm{m}^{3}$ ) for Guatemala grass, $31.3 \mathrm{~km} / \mathrm{m}^{3}$ (stdev $0.3 \mathrm{~km} / \mathrm{m}^{3}$ ) for Napier grass and $10.5 \mathrm{~km} / \mathrm{m}^{3}$ (stdev = $3.4 \mathrm{~km} / \mathrm{m}^{3}$ ) for Tithonia shrub in Majulai whereas in Migambo village the values were 45.0 $\mathrm{km} / \mathrm{m}^{3}\left(\mathrm{stdev}=13.1 \mathrm{~km} / \mathrm{m}^{3}\right)$ for Guatemala grass, $150.0 \mathrm{~km} / \mathrm{m}^{3}\left(\right.$ stdev $\left.=8.1 \mathrm{~km} / \mathrm{m}^{3}\right)$ for 
Napier grass and $6.4 \mathrm{~km} / \mathrm{m}^{3}$ (stdev $=2.1 \mathrm{~km} / \mathrm{m}^{3}$ ) for Tithonia shrub. In Majulai village mean $\mathrm{RD}$ at $0-0.4 \mathrm{~m}$ for Guatemala grass was significantly higher at $5 \%$ level $(P=.003)$ than for Napier grass or Tithonia shrub whereas RLD values for Guatemala grass and Napier grass were significantly higher at $5 \%$ level $(P<.001)$ than Tithonia shrub. In Migambo village, mean RLD for Napier grass at $0-0.4 \mathrm{~m}$ soil depth was higher at $5 \%$ level $(P=.009)$ than Guatemala grass or Tithonia shrub whereas RD for Guatemala grass was higher at $5 \%$ level $(P=.002)$ when compared with Napier grass and Tithonia shrub. Plants sampled in Migambo village have higher RD and RLD values when compared with plants investigated in Majulai village. This is explained by the different agro-ecological conditions whereby Migambo has more favourable conditions (larger and well distributed rainfall and lower air temperature) for plant growth as compared to Majulai village which is drier and warm. [10] reported higher root densities in some habitats to be linked with the availability of soil moisture content and therefore, species growing in channels and on steep badland slopes had more roots at greater depths compared to species growing on flat, gently sloping abandoned fields. According [5] measurements of grass RLD, in pastures located in the loess belt of Belgium, range between 740 and $6190 \mathrm{~km} / \mathrm{m}^{3}\left(\mathrm{n}=32\right.$, mean $=2310 \mathrm{~km} / \mathrm{m}^{3}$, stdev $=1200 \mathrm{~km} / \mathrm{m}^{3}$ ), indicating that the RLD values for the studied plants are lower than pasture grass in Belgium. This can be due to the fact that pasture grass has finer roots than the studied plants.

\subsection{Root Distribution with Soil Depth for the Studied Plants}

The distribution of roots with soil depth is presented in Fig. 3. In both villages, RD of the studied plant species decreased with soil depth, however mean RSD increased with soil depth. This observation was also made by $[10,21]$ whereby RD of 26 plant species studied decreased with soil depth. Root length density decreased with soil depth in Majulai, while in Migambo RLD for Guatemala grass and Tithonia shrub tended to increase at deeper soil depths; which is probably due to reliable and well distributed rainfall favorable for plant growth through promoting finer roots at deeper soil depths in Migambo than in Majulai village. Root area ratio followed the same trend as that observed for RLD.

\subsection{Selection of the Most Effective Plant for Soil Erosion Control}

The relationships established by [7] to predict the erosion-reducing effect of root systems were applied in this study. The idea was to apply these for tropical grasses which have comparable root systems but which are growing in different soil types. We therefore aim at obtaining a first indication of the relative effectiveness of the studied plants species for controlling concentrated flow erosion.

It was observed that the predicted RSD values were generally lowest in the topsoil and increased with an increasing soil depth (and with decreasing RD) (Table 3, Fig. 3). Similar observation was reported by $[13,22]$ where soil erodibility decreased with increasing RD. Mean predicted RSD values at $0-0.4 \mathrm{~m}$ soil depth for Majulai and Migambo were respectively $4.43^{*} 10^{-12}$ and $1.20^{*} 10^{-14}$ for Guatemala grass, $6.10^{*} 10^{-5}$ and $2.74^{*} 10^{-4}$ for Napier grass and $4.43^{*} 10^{-3}$ and $2.24^{*} 10^{-4}$ for Tithonia shrub, indicating that plant roots can have a significant effect on soil resistance to erosion and that this effect is largely dependent on plant species. Lower RSD rates in Migambo than in Majulai can be attributed to the presence of more favorable environmental conditions in Migambo which are responsible for greater plant growth. Mean RSD values for the $0-0.4 \mathrm{~m}$ soil depth were not significantly different at $5 \%$ level $(P=.37)$ in Majulai and $(P=.56)$ in Migambo village. According to [10] the predicted RSD values of the studied plants ranked very high (RSD $<0.01)$, with erosionreducing potential in the following order Guatemala grass $>$ Napier grass $>$ Tithonia shrub. 

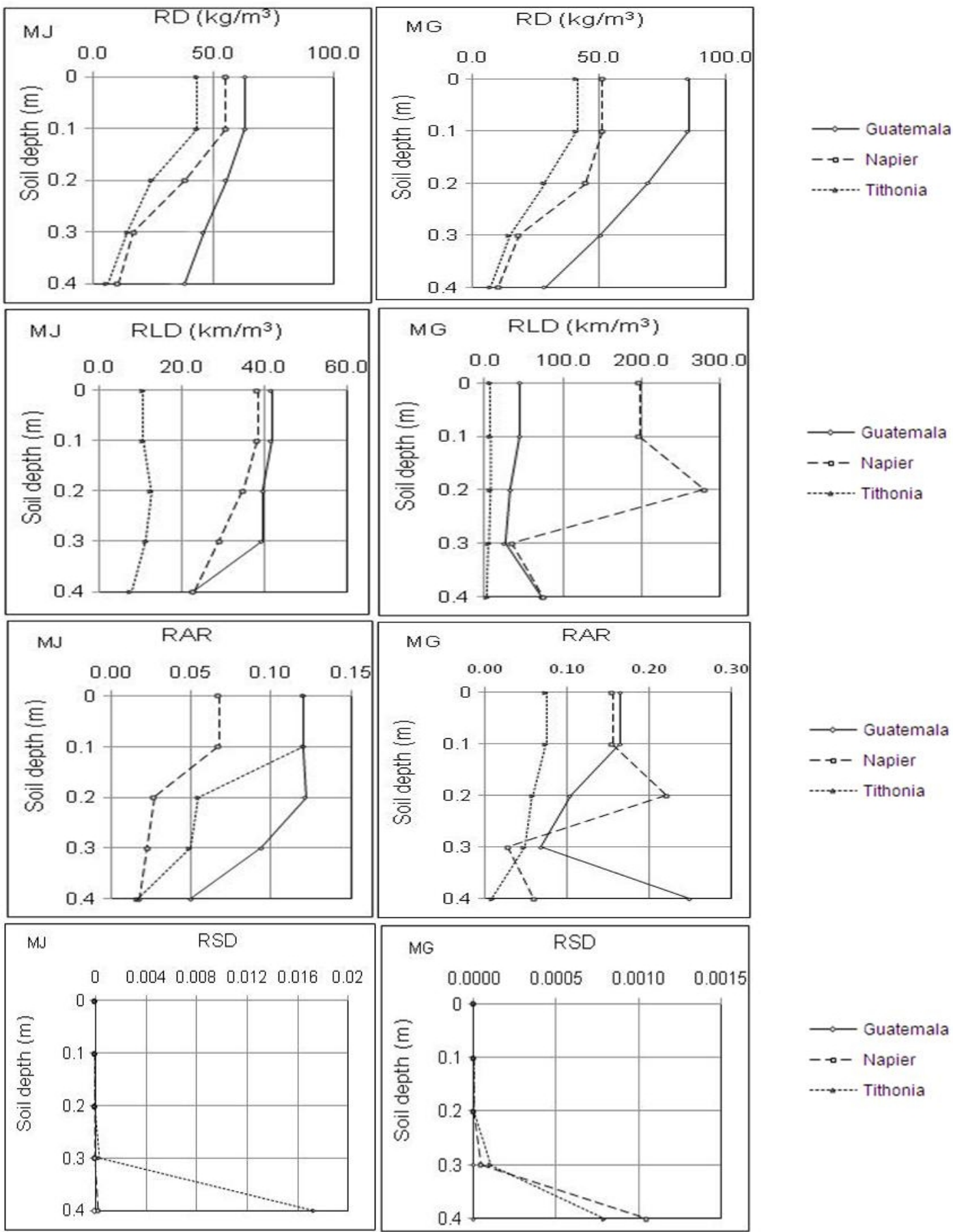

Fig. 3. Variation of root properties with soil depth and their erosion-reducing potentials for the studied plants in Majulai (MJ) and Migambo (MG) villages. RD is root density; RLD is root length density; RAR is root area ratio; RSD is relative soil detachment rate 
Table 3. Mean root characteristics of the studied plants and effects of roots on predicted RSD in the Usambara Mountains

\begin{tabular}{|c|c|c|c|c|c|c|}
\hline Plant & $\begin{array}{l}\text { Type of } \\
\text { plant }\end{array}$ & $\begin{array}{l}\text { Soil depth } \\
\text { (m) }\end{array}$ & $\mathbf{n}$ & $\begin{array}{l}\text { RD } \\
\left(\mathrm{kg} / \mathrm{m}^{3}\right)\end{array}$ & $\begin{array}{l}\text { RLD } \\
\left(\mathrm{km} / \mathrm{m}^{3)}\right.\end{array}$ & RSD \\
\hline \multicolumn{7}{|c|}{ Majulai village } \\
\hline Guatemala & Grass & $0-0.1$ & 3 & 63.4 & 41.8 & $6.86 * 10^{-21}$ \\
\hline Napier & Grass & $0-0.1$ & 3 & 55.1 & 38.4 & $1.74 * 10^{-32}$ \\
\hline Tithonia & Shrub & $0-0.1$ & 3 & 43.2 & 10.6 & $2.18^{*} 10^{-6}$ \\
\hline Guatemala & Grass & $0.1-0.2$ & 3 & 55.4 & 39.7 & $2.54 * 10^{-24}$ \\
\hline Napier & Grass & $0.1-0.2$ & 3 & 38.4 & 34.8 & $9.99 * 10^{-1 /}$ \\
\hline Tithonia & Shrub & $0.1-0.2$ & 3 & 24.6 & 12.6 & $1.15^{*} 10^{-y}$ \\
\hline Guatemala & Grass & $0.2-0.3$ & 3 & 46.3 & 39.5 & $1.29 * 10^{-16}$ \\
\hline Napier & Grass & $0.2-0.3$ & 3 & 17.3 & 29.1 & $1.37^{*} 10^{-10}$ \\
\hline Tithonia & Shrub & $0.2-0.3$ & 3 & 14.5 & 11.3 & $3.47^{*} 10^{-4}$ \\
\hline Guatemala & Grass & $0.3-0.4$ & 3 & 38.6 & 22.7 & $1.77^{*} 10^{-11}$ \\
\hline Napier & Grass & $0.3-0.4$ & 3 & 10.6 & 22.8 & $2.44^{*} 10^{-4}$ \\
\hline Tithonia & Shrub & $0.3-0.4$ & 3 & 6.1 & 7.6 & $1.74 * 10^{-2}$ \\
\hline $\operatorname{LSD}(P=.05)$ & & & & 15.9 & 5.1 & $7.29 * 10^{-3}$ \\
\hline \multicolumn{7}{|c|}{ Migambo village } \\
\hline Guatemala & Grass & $0-0.1$ & 3 & 85.4 & 45.0 & $2.66 * 10^{-42}$ \\
\hline Napier & Grass & $0-0.1$ & 3 & 51.4 & 200.0 & $1.33 * 10^{-16}$ \\
\hline Tithonia & Shrub & $0-0.1$ & 3 & 41.5 & 7.6 & $3.07^{*} 10^{-15}$ \\
\hline Guatemala & Grass & $0.1-0.2$ & 3 & 69.6 & 34.0 & $2.60 * 10^{-33}$ \\
\hline Napier & Grass & $0.1-0.2$ & 3 & 45.0 & 280.0 & $1.32 * 10^{-10}$ \\
\hline Tithonia & Shrub & $0.1-0.2$ & 3 & 28.6 & 8.5 & $4.25^{*} 10^{-9}$ \\
\hline Guatemala & Grass & $0.2-0.3$ & 3 & 50.9 & 27.0 & $4.89 * 10^{-23}$ \\
\hline Napier & Grass & $0.2-0.3$ & 3 & 18.3 & 36.0 & $4.71 * 10^{-5}$ \\
\hline Tithonia & Shrub & $0.2-0.3$ & 3 & 14.7 & 6.1 & $1.03 * 10^{-4}$ \\
\hline Guatemala & Grass & $0.3-0.4$ & 3 & 28.7 & 73.0 & $4.79 * 10^{-14}$ \\
\hline Napier & Grass & $0.3-0.4$ & 3 & 10.3 & 76.0 & $1.05^{*} 10^{-3}$ \\
\hline Tithonia & Shrub & $0.3-0.4$ & 3 & 7.1 & 3.4 & $7.92 * 10^{-4}$ \\
\hline $\operatorname{LSD}(P=.05)$ & & & & 18.7 & 89.0 & $5.51 * 10^{-4}$ \\
\hline
\end{tabular}

$n$ is the number of plants sampled per species; $R D$ is root density; RLD is root length density; RSD is relative soil detachment rate

Guatemala grass had the highest erosion-reducing potential and hence has potential to increase the resistance of topsoil to concentrated flow erosion to a large extent. This is attributed to the high density of fine roots in the topsoil. The mean RD values at the $0-0.4$ $\mathrm{m}$ soil depth were significantly higher at $5 \%$ level $(P=.003)$ in Majulai village and $(P=.002)$ in Migambo village for Guatemala grass when compared to Napier grass and Tithonia shrub. However, Guatemala and Napier grass roots had higher protection to the $0-0.20 \mathrm{~m}$ thick topsoil as it was observed that the erosion-reducing effect of these grass roots decreased very rapidly with increasing soil depth when compared to Tithonia shrub. Guatemala and Napier grasses had high RD values and the large proportion of their fine roots makes them suitable for reducing concentrated flow erosion rates from the topsoil. The low erosion reducing potential of Tithonia shrub can be attributed to the rather low RD and/or to the absence of a fine root network in the topsoil. The erosion-reducing effect of Tithonia shrub is more pronounced at greater depths $(0.2$ to $0.3 \mathrm{~m})$, which can be attributed to the presence of smaller roots at larger depths. This observation is supported by the work of [7] who found that erosion-reducing effects of RD decreased with increasing root diameter. 


\subsection{Comparison with Other Studies on Root Densities of the Tropical Grass Species}

[8] also studied rooting characteristics of tropical grass species and their effects as sediment filters in the riparian zone of Lake Victoria in Uganda where RD of Paspalum grass, Lemon grass, Elephant grass and Sugarcane were investigated. The results show that RD for $0-$ $0.4 \mathrm{~m}$ soil depth were $20.6 \mathrm{~kg} / \mathrm{m}^{3}$ for Paspalum, $7.6 \mathrm{~kg} / \mathrm{m}^{3}$ for Lemon grass, $3.8 \mathrm{~kg} / \mathrm{m}^{3}$ for Elephant grass and $5.1 \mathrm{~kg} / \mathrm{m}^{3}$ for Sugarcane. In Fig. 4 the RD distribution with soil depth for the $0-0.4 \mathrm{~m}$ depth is compared between this study and findings by [8]. For both studies root densities decreased with soil depth. However, this study had higher RD values than the results of [8] except for Paspalum grass which had relatively similar RD values compared to that of Guatemala grass for the top $0-0.1 \mathrm{~m}$ soil depth (Fig. 4).
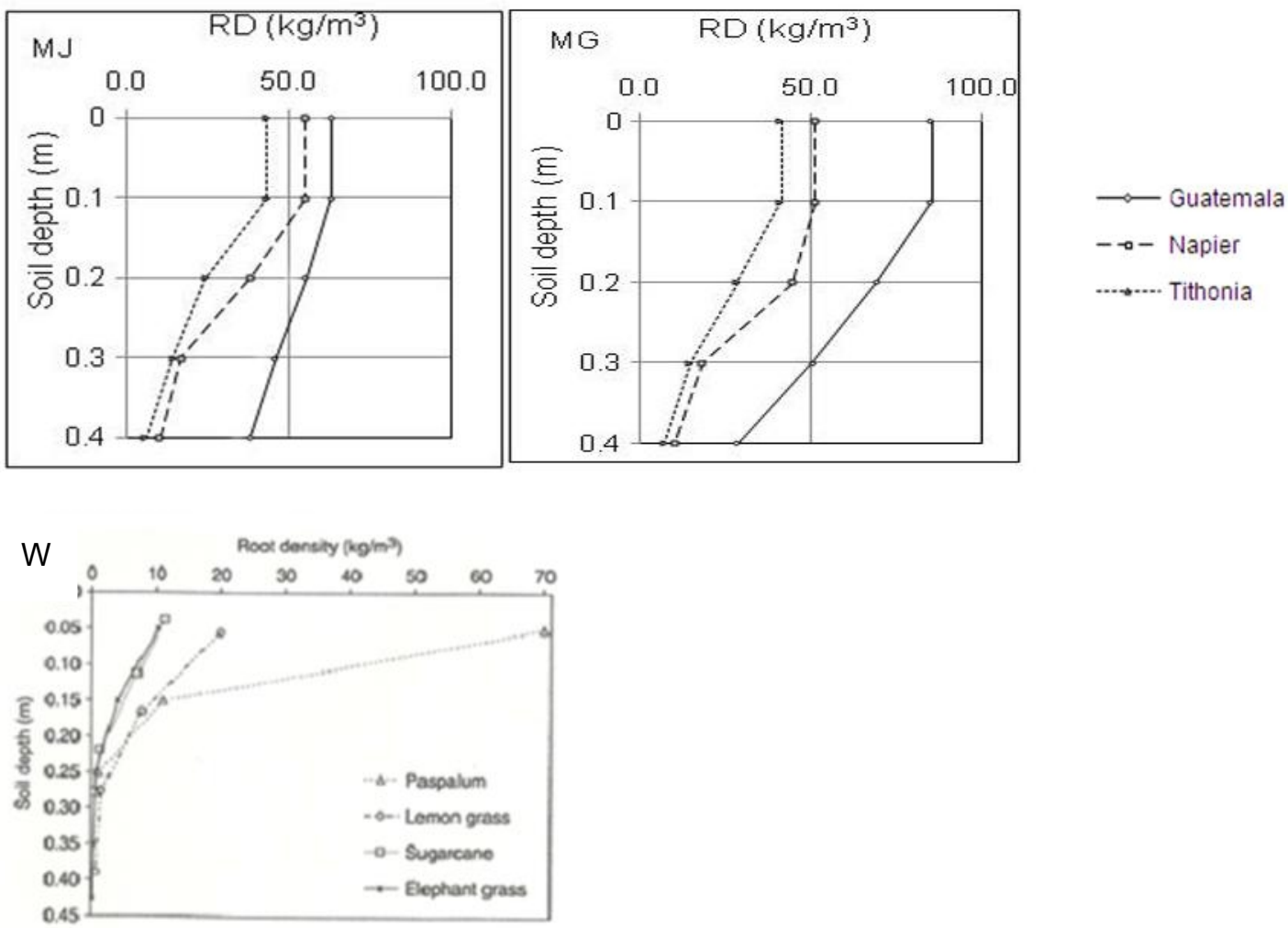

Fig. 4. Comparing tropical grass species root densities of the studied grasses in Usambara Mountains, Tanzania (MJ \& MG) and grasses in Lake Victoria, Uganda (W) according to Wanyama et al. (2012). MJ is Majulai village, MG is Migambo village

\section{CONCLUSIONS}

Guatemala and Napier grasses $100 \%$ root mass consisted of root diameter less than $5 \mathrm{~mm}$, while Tithonia shrub had a root mass with $70 \%$ of root diameters less than $5 \mathrm{~mm}$ and $30 \%$ greater than $5 \mathrm{~mm}$. Guatemala grass had highest values of RD followed by Napier grass and Tithonia shrub (the least) in $0-0.4 \mathrm{~m}$ soil depth, while RLD values for Guatemala and 
Napier grasses were almost the same in Majulai with low values for Tithonia shrub in both villages, whereas in Migambo Napier grass had very high values. Guatemala grass is the most effective species in reducing concentrated flow erosion rates in topsoil $(0-0.4 \mathrm{~m})$, followed by Napier grass while Tithonia shrub is the least effective. The erosion reducing potential of Tithonia shrub is more pronounced at greater depths.

Based on the analysis of the root properties of the studied plants, Guatemala grass is strongly recommended for use in concentrated flow erosion control in the study area. However, a combination of Guatemala grass or Napier grass and Tithonia shrub will result in a better protection of the topsoil at greater soil depths, but their compatibility should be investigated. In-depth studies to investigate physical RSD for different soil textures are recommended in order to come up with more representative RSD models. Studies are needed to evaluate more plants growing in various habitats for selection of plant species that can effectively control concentrated flow erosion rates.

\section{ACKNOWLEDGEMENTS}

The authors are grateful to the VLIR-UOS supported RIP-DSS SUA Project "Enhancing Indigenous Knowledge on Conservation Agriculture for Poverty Alleviation and Sustainable Livelihood, Usambara Mountains, Lushoto, Tanzania", for providing financial and logistical assistance to the research. The first author is grateful to the Tanzania Commission of Science and Technology (COSTECH) for sponsoring PhD programme that contributed to the production of this paper.

\section{COMPETING INTERESTS}

Authors have declared that no competing interests exist.

\section{REFERENCES}

1. Vigiak O, Okoba BO, Sterk G, Stroosnijder L. Water erosion assessment using farmers' indicators in the Western Usambara Mountains, Tanzania. CATENA. 2005;64:307-320.

2. Tenge AJM. Participatory appraisal for farm level soil and water conservation planning in West Usambara highlands, Tanzania. PhD Thesis, Wageningen University. Dissertation. 2005;3733.

3. Msita HB. Insights into indigenous soil and water conservation technologies in Western Usambara Mountains, Tanzania. PhD dissertation KU Leuven Belgium: 2013;198.

4. Cook BG, Pengelly BC, Brown SD, Donnelly JL, Eagles DA, Franco MA, Hanson J, Muller BF, Petriedge IJ, Peters M, Schultze-Kraft R. Tropical forages. CSIRO, DPI \& F(Qid), CIAT and ILRI, Brisbane, Australia; 2006.

5. De Baets S, Poesen J, Gyssels G, Knapen A. Effects of grass roots on the erodibility of topsoil during concentrated flow. Geomorphology. 2006;76:54-67.

6. Poesen J, De Baets S. The effects of plant root characteristics on soil erosion. Chapter 4.3. In Hooke E. (Ed.) Conditions for Restoration \& Mitigation of Desertified Areas Using Vegetation (RECONDES). Review of literature and present knowledge. European Commission, Brussels; 2006. 
7. De Baets S, Poesen J, Knapen A, Galindo P. Impact of root architecture on the erosion-reducing potential of roots during concentrated flow. Earth Surface Processes and Landforms. 2007a;32:1323-1345.

8. Wanyama J, Herremans K, Maetens W, Isabirye M, Kahimba F, Kimaro D, Poesen J, Deckers $\mathrm{J}$. Effectiveness of tropical grass species as sediment filters in the riparian zone of Lake Victoria. Soil Use and Management. 2012;28:409-418.

9. Gyssels G, Poesen J, Bochet E, Li Y. Impact of plant roots on the resistance of soils to erosion by water: A review. Progress in Physical Geography. 2005;29(2):189-217.

10. De Baets S, Poesen J, Knapen A, Barberá GG, Navarro JA. Root characteristics of representative Mediterranean plant species and their erosion-reducing potential during concentrated runoff. Plant and Soil. 2007b;294:169-183.

11. Kyaruzi LA. Relationship between soil and landform derived land qualities and conservation agriculture practices in West Usambara Mountains, Tanzania. M.Sc. Dissertation, Sokoine University of Agriculture, Morogoro Tanzania. 2013;140.

12. Tenge AJ, De Graaff J, Hella JP. Social and economic factors affecting the adoption of soil and water conservation in West Usambara highlands Tanzania. Land degradation and development. 2004;5:99-114.

13. De Baets S, Poesen J, Reubens B, Muys B, De Baerdemaeker J, Meersmans J. Methodological framework to select plant species for controlling rill and gully erosion: application to a Mediterranean ecosystem. Earth Surface Processes and Landforms. 2009; 34: 1374 -1392.

14. De Baets S, Torri D, Poesen J, Salvador MP, Meersmans J. Modelling increased soil cohesion due to roots with EUROSEM. Earth Surface Processes and Landforms. 2008;33:1948-1963.

15. Moberg JP. Soil and plant analysis manual. The Royal Veterinary and Agricultural University, Chemistry Department, Copenhagen, Denmark. 2001;133.

16. Smit AL, Bengough AG, Engels C, Van Noordwijk M, Pellerin S, Van de Geijn SC. Root methods: A handbook. Springer-Verlag, Berlin. 2000;587.

17. MapInfo Professional. Earth Science and GIS Software, Pitney Bowes Software Inc. One Global View, Troy, New York, USA. 2012;12180-8399.

18. Genstat. Introduction to Genstat 14 for Windows. Statistical service centre, University of Reading UK. 2011;41.

19. Lynch J. Root architecture and plant productivity. Plant Physiology. 1995;109:7-13.

20. Godin C. Representing and encoding plant architecture: A review. Annuals of Forest Science. 2000;57:413-438.

21. Poesen J, Knapen A, Barbera G, Navarro AJ. Root characteristics of representative Mediterranean plant species and their erosion-reducing potential during concentrated runoff. Springer Science + Business Media B.V.; 2007.

22. De Baets $\mathrm{S}$, Poesen J. Empirical models for predicting the erosion-reducing effects of plant roots during concentrated flow erosion. Geomorphology. 2010;118:425-432.

(c) 2014 Mwango et al.; This is an Open Access article distributed under the terms of the Creative Commons Attribution License (http://creativecommons.org/licenses/by/3.0), which permits unrestricted use, distribution, and reproduction in any medium, provided the original work is properly cited.

Peer-review history:

The peer review history for this paper can be accessed here: http://www.sciencedomain.org/review-history.php?iid=620\&id=24\&aid=5888 